\title{
Relation between small airways disease and parenchymal destruction in surgical lung specimens
}

\author{
Luuk NA Willems, Johannes A Kramps, Theo Stijnen, Peter J Sterk, Jan J Weening, \\ Joop H Dijkman
}

\begin{abstract}
The relation between small airways disease and parenchymal destruction was investigated in lungs and lobes removed at surgery from 27 patients aged 15-70 years. Eight of the 27 patients were lifelong non-smokers. The degree of small airways disease was assessed by semiquantitative grading (SAD score) and by measuring diameter and wall thickness of membranous bronchioles. Parenchymal destruction was measured in three ways. Firstly, the number of alveolar attachments on membranous bronchioles per millimetre of circumference (AA/mm) was counted; the number of broken attachments was subtracted from the total $A A / \mathbf{m m}$ to give the numbers of intact attachments (normal AA/ mm). Secondly, a point counting technique was used to give a destructive index (DI). Thirdly, the mean linear intercept $(\mathrm{Lm})$ was determined. Total and normal AA/ mm correlated negatively with the SAD score of membranous bronchioles $\left(r_{\mathrm{s}}=\right.$ -0.48 and -0.51$)$ and with wall thickness $\left(r_{s}=-0.37\right.$ and -0.45$)$ and DI correlated with wall thickness $\left(r_{s}=0.5\right)$ and with the SAD score of respiratory bronchioles $\left(r_{s}\right.$ $=0.53)$. Lm did not correlate with indices of small airway disease and total and normal $\mathbf{A A} / \mathbf{m m}$ did not correlate with diameter. Multiple regression analyses showed that the correlation of total AA/ $\mathrm{mm}$ with the SAD score of membranous and respiratory bronchioles and with wall thickness were not confounded by age or smoking. It is concluded that small airways disease is related to destruction of peribronchiolar alveoli, and it is postulated that small airways disease has a direct role in the causation of centrilobular emphysema.
\end{abstract}

Small airways disease and pulmonary emphysema are two diseases that occur in the distal parts of the human lung and are linked aetiologically to cigarette smoking. Small airways disease, recognised by Hogg et al as a collection of histological features of chronic inflammation in airways with an internal diameter of less than $2 \mathrm{~mm}$, was considered to be responsible for airflow obstruction in cigarette smokers. ${ }^{1}$ Since then several studies have confirmed the susceptibility of smokers to develop morphological bronchiolar lesions leading to lung function abnormalities. ${ }^{2-4}$ Pulmonary emphysema is characterised by abnormal, permanent enlargement of airspaces distal to the terminal bronchiole, accompanied by destruction of their walls and without obvious fibrosis. ${ }^{5}$ It is beyond doubt that cigarette smoking is important in the pathogenesis of this condition as well. ${ }^{6}$

As features of small airways disease and emphysema are often present in the same lung, possibly both diseases not only have a common aetiologic factor but are causally linked. The possibility that small airway inflammation may lead to emphysema was put forward 30 years ago by Leopold and Gough ${ }^{7}$ and later by Anderson and Foraker. ${ }^{8}$ The inflammatory process in the airways could lead to a weakening of surrounding alveolar walls, or it could be responsible for an imbalance between proteinases and their inhibitors, which it is thought will induce emphysema. ${ }^{9}$ Recent studies on destructive lesions of alveolar attachments on bronchioles suggest that indeed this might happen. ${ }^{1011}$ The events may also develop in the reverse order: loss of alveolar walls around bronchioles might lead to abnormal bronchiolar morphology. ${ }^{112}$ In either case parenchymal and bronchiolar disease might be expected to share the same distribution pattern within the lung. Some investigators have tried to prove such a topographic association by comparing upper and lower lobes, but have obtained contradictory results. ${ }^{31314}$ If small airways disease does lead to the development of emphysema, it would be expected to occur at an earlier stage than emphysema. Recently, however, Petty et al ${ }^{15}$ found minimal differences in small airway disease and no differences in $\mathrm{FEV}_{1}$ or closing capacity between normal and mild emphysematous lungs. The precise relation between small airways disease and the development of emphysema remains to be determined. ${ }^{16}$

The purpose of our study was to look for evidence for a causal relation between small airways disease and emphysema by performing microscopic measurements for these two pathological conditions in surgical lung specimens.

\section{Methods}

PATIENTS

Lungs and lobes were obtained from 19 male 
and 8 female patients who were treated by surgery for a solitary lesion in the lung. Eight were lifelong non-smokers. The subjects were not deficient for $\alpha_{1}$ proteinase inhibitor (PiZZ or PiSZ), determined by phenotyping using isoelectric focusing, and did not have any disease known to influence lung structure other than chronic bronchitis or emphysema. Pulmonary function tests were performed preoperatively according to standardised methods. ${ }^{17}$ Six subjects had an $\mathrm{FEV}_{1}$ below $80 \%$ predicted. ${ }^{17}$ The mean $\mathrm{FEV}_{1}$ of the subjects was $86 \%$ predicted (range $44.9-$ $114 \%$ ), vital capacity $94.1 \%$ predicted (range $80 \cdot 0-111 \cdot 6 \%$ ), and residual volume $117.6 \%$ predicted (range 67.0-166.5\%). Surgical specimens unsuitable for inflation were excluded.

\section{TISSUE PROCESSING}

Within one hour of surgical removal the lung specimens were inflated via the airway with Bouin's fixative by balloon tipped catheters to a distending pressure of $25 \mathrm{~cm}$ fixative for four hours. The specimens were then sliced and tissue blocks were sampled from each slice randomly; processed to paraplast; cut into $4 \mu \mathrm{m}$ sections; and stained with haematoxylin-eosin, van Gieson, Verhoeff-van Gieson, and periodic acid-Schiff after treatment with amylase.

\section{MORPHOMETRY}

Small airways disease

Small airways disease was graded semiquantitatively according to the method of Cosio $e t a l^{18}$ on the basis of reference pictures. Respiratory bronchioles were graded for mural chronic cellular infiltrate, pigment deposition, muscle hypertrophy, fibrosis, and goblet cell metaplasia. Membranous bronchioles were graded for the same features and for squamous cell metaplasia in addition. For each bronchiole the scores for all the features were summed and expressed as a percentage of the maximum possible small airway disease (SAD) score, all features thus being given the same weight in each bronchiole.

In membranous bronchioles the external adventitial and internal basal laminar diameters were measured by dividing the perimeter, as measured on a digitising tablet, by $\pi$. Wall thickness was calculated by subtracting the internal from the external diameter, and dividing the difference by 2 . Tangentially or obliquely sectioned bronchioles were eliminated.

\section{Parenchymal destruction}

The number of alveolar attachments on membranous bronchioles per $\mathrm{mm}$ of perimeter was counted (AA/mm). Disrupted or broken attachments were subtracted from the total number per bronchiole (total $\mathrm{AA} / \mathrm{mm}$ ) to give the number of intact attachments (normal AA/ $\mathrm{mm}$ ), a method similar to that of Saetta et al being used. ${ }^{10}$ Bronchioles with a quarter or more of their perimeter bordered by nonparenchymal structures were excluded.

A microscopic point counting technique was used in six sections of each lobectomy specimen and in four sections of both upper and lower lobes of the pneumectomy specimens to obtain the percentage of airspaces that were destroyed-that is, the destructive index or DI. ${ }^{19}$ This was done using a $\times 10$ objective and a $\times 8$ eyepiece containing a counting grid. Each airspace, coinciding with a crossing point of the grid, was assessed, and defined as being destroyed when it met one of the following criteria: (1) Two or more breaks in the alveolar wall; (2) two or more parenchymal rags in the lumen of alveolar ducts; (3) clearly abnormal morphology; (4) classic emphysematous change. ${ }^{19}$ About 500 points were evaluated in each tissue section.

The mean linear intercept (Lm) was measured in tissue sections according to the method of Dunnill..$^{20}$ Dimensions were corrected for tissue shrinkage after fixation; ${ }^{21}$ the linear shrinkage factor was found to be $0 \cdot 81$. All measurements were performed by the same observer. Intraobserver agreement, expressed as the correlation between two readings of tissue sections, ranged from 0.78 to 0.99 for bronchiolar measurements and from 0.62 to 0.88 for parenchymal measurements.

\section{STATISTICAL ANALYSIS}

Data on bronchioles and parenchyma in all the tissue sections were averaged. The mean data for each subject were computed from the average tissue section data. The association between two variables was evaluated by use of the Spearman rank correlation coefficient $\left(r_{s}\right)$.

Differences between upper and lower lobes regarding bronchiolar and parenchymal variables were evaluated by a two sample $t$ test. Data from the lower lobes from the six pneumonectomy cases were added to those from the eight lower lobectomy cases. These 14 lower lobes were compared with the specimens from the 12 upper lobectomy cases.

Multiple regression analyses on the basis of all 27 cases were performed to assess whether correlations between bronchiolar and parenchymal variables would still be significant when age and smoking history were included in the calculations.

\section{Results}

The age of the subjects, the resected areas, and the morphometric data are presented in table 1.

The correlations between bronchiolar and parenchymal variables of the 27 lung specimens are shown in table 2 . There was a significant negative correlation between total and normal $\mathrm{AA} / \mathrm{mm}$ and the SAD scores of membranous bronchioles, and between normal $\mathrm{AA} / \mathrm{mm}$ and wall thickness (see figs 1 and 2). The destructive index was positively correlated with goblet cell metaplasia and wall thickness of membranous bronchioles and with SAD score, goblet cell metaplasia, and fibrosis of respiratory bronchioles. There was no significant correlation of $\mathrm{Lm}$ with any of the bronchiolar variables.

Data on the upper and lower lobes are compared in table 3. Total and normal AA $/ \mathrm{mm}$ values were significantly lower in the upper 
Table 1 Age of the subjects and morphological characteristics of the 27 lung specimens

\begin{tabular}{|c|c|c|c|c|c|c|c|c|c|c|}
\hline \multirow[b]{2}{*}{$\begin{array}{l}\text { Subject } \\
\text { No }\end{array}$} & \multirow[b]{2}{*}{$\begin{array}{l}\text { Age } \\
(y)\end{array}$} & \multirow[b]{2}{*}{$\begin{array}{l}\text { Pack } \\
\text { years }\end{array}$} & \multirow[b]{2}{*}{$\begin{array}{l}\text { Resected } \\
\text { area }\end{array}$} & \multicolumn{2}{|c|}{ Membranous bronchioles } & \multirow{2}{*}{$\frac{\text { Respiratory bronchioles }}{\text { SAD score }}$} & \multicolumn{4}{|c|}{ Parenchymal variables } \\
\hline & & & & $\underset{\left(\begin{array}{c}0 \\
0\end{array}\right)}{S A D \text { score }}$ & $\begin{array}{l}\text { Wall thickness } \\
(\mathrm{mm})\end{array}$ & & $\begin{array}{l}D I \\
\left(\begin{array}{c}0 \\
0\end{array}\right)\end{array}$ & $\begin{array}{l}\mathrm{Lm} \\
(\mathrm{mm})\end{array}$ & $\begin{array}{l}\text { Total } \\
A A / \mathrm{mm}\end{array}$ & $\begin{array}{l}\text { Normal } \\
A A / m m\end{array}$ \\
\hline $\begin{array}{l}\text { NON-SMC } \\
1 \\
2 \\
3 \\
4 \\
5 \\
6 \\
7 \\
8 \\
\text { Mean } \\
\text { SD }\end{array}$ & $\begin{array}{c}\text { RS } \\
63 \\
59 \\
68 \\
15 \\
69 \\
49 \\
59 \\
22 \\
50 \cdot 5 \\
(20 \cdot 8)\end{array}$ & $\begin{array}{l}0 \\
0 \\
0 \\
0 \\
0 \\
0 \\
0 \\
0\end{array}$ & $\begin{array}{l}\text { LLU* } \\
\text { LUL } \\
\text { LUL } \\
\text { LLL } \\
\text { RLL } \\
\text { RLL } \\
\text { LLL } \\
\text { RLL }\end{array}$ & $\begin{array}{c}30 \cdot 16 \\
26 \cdot 97 \\
27 \cdot 78 \\
13 \cdot 11 \\
21.47 \\
26 \cdot 39 \\
22 \cdot 83 \\
13 \cdot 56 \\
22 \cdot 78 \\
(6 \cdot 44)\end{array}$ & $\begin{array}{c}0.08 \\
0.06 \\
0.06 \\
0.05 \\
0.05 \\
0.08 \\
0.07 \\
0.05 \\
0.06 \\
(0.01)\end{array}$ & $\begin{array}{c}25 \cdot 79 \\
24 \cdot 31 \\
17 \cdot 92 \\
9 \cdot 59 \\
16 \cdot 60 \\
21 \cdot 63 \\
16 \cdot 12 \\
9 \cdot 17 \\
17 \cdot 64 \\
(6 \cdot 17)\end{array}$ & $\begin{array}{r}17 \\
8 \\
20 \\
3 \\
23 \\
14 \\
32 \\
2 \\
15 \\
(10)\end{array}$ & $\begin{array}{c}0.310 \\
0 \cdot 252 \\
0.351 \\
0.246 \\
0.383 \\
0 \cdot 339 \\
0.389 \\
0.214 \\
0.311 \\
(0.66)\end{array}$ & $\begin{array}{c}7 \cdot 01 \\
7 \cdot 50 \\
7 \cdot 09 \\
7.93 \\
8 \cdot 09 \\
7 \cdot 37 \\
8 \cdot 41 \\
9 \cdot 17 \\
7 \cdot 82 \\
(0 \cdot 73)\end{array}$ & $\begin{array}{c}5 \cdot 09 \\
7 \cdot 10 \\
6 \cdot 50 \\
7 \cdot 63 \\
7 \cdot 66 \\
7 \cdot 11 \\
7 \cdot 75 \\
8 \cdot 83 \\
7 \cdot 21 \\
(1 \cdot 09)\end{array}$ \\
\hline $\begin{array}{l}\text { SMOKERS } \\
9 \\
10 \\
11 \\
12 \\
13 \\
14 \\
15 \\
16 \\
17 \\
18 \\
19 \\
20 \\
21 \\
22 \\
23 \\
24 \\
25 \\
26 \\
27\end{array}$ & $\begin{array}{l}\text { D EX-SM } \\
66 \\
43 \\
65 \\
61 \\
32 \\
59 \\
47 \\
66 \\
64 \\
58 \\
56 \\
63 \\
52 \\
65 \\
70 \\
67 \\
60 \\
67 \\
62\end{array}$ & $\begin{array}{c}\text { KERS } \\
59 \\
27 \\
45 \\
32 \\
24 \\
24 \\
78 \\
16 \\
95 \\
55 \\
34 \\
36 \\
24 \\
+ \\
+ \\
13 \\
63 \\
52 \\
9\end{array}$ & $\begin{array}{l}\text { RUL } \\
\text { LLL } \\
\text { LLU } \\
\text { RUL } \\
\text { RUL } \\
\text { RUL } \\
\text { LUL } \\
\text { RLU } \\
\text { RUL } \\
\text { LUL } \\
\text { RUL } \\
\text { LLL } \\
\text { LUL } \\
\text { LLU } \\
\text { RLU } \\
\text { RLU } \\
\text { RLL } \\
\text { RLU } \\
\text { RUL }\end{array}$ & $\begin{array}{l}27 \cdot 00 \\
20 \cdot 08 \\
21 \cdot 74 \\
33 \cdot 51 \\
19 \cdot 77 \\
21 \cdot 30 \\
20 \cdot 03 \\
23 \cdot 67 \\
26 \cdot 56 \\
29 \cdot 22 \\
20 \cdot 44 \\
22 \cdot 21 \\
34 \cdot 01 \\
17 \cdot 12 \\
23.97 \\
21 \cdot 11 \\
29 \cdot 78 \\
26 \cdot 85 \\
15 \cdot 89\end{array}$ & $\begin{array}{l}0.11 \\
0.06 \\
0.05 \\
0.09 \\
0.07 \\
0.08 \\
0.08 \\
0.06 \\
0.07 \\
0.08 \\
0.08 \\
0.06 \\
0.13 \\
0.07 \\
0.07 \\
0.07 \\
0.07 \\
0.07 \\
0.05\end{array}$ & $\begin{array}{l}26 \cdot 15 \\
18 \cdot 78 \\
22 \cdot 53 \\
34 \cdot 01 \\
20 \cdot 40 \\
29 \cdot 68 \\
27 \cdot 79 \\
27 \cdot 36 \\
30 \cdot 99 \\
34 \cdot 79 \\
25 \cdot 38 \\
19 \cdot 50 \\
36 \cdot 67 \\
20 \cdot 83 \\
27 \cdot 77 \\
25 \cdot 04 \\
40 \cdot 89 \\
30 \cdot 17 \\
13 \cdot 72\end{array}$ & $\begin{array}{r}43 \\
9 \\
27 \\
46 \\
26 \\
26 \\
15 \\
40 \\
30 \\
43 \\
48 \\
35 \\
34 \\
41 \\
48 \\
49 \\
45 \\
26 \\
19\end{array}$ & $\begin{array}{l}0 \cdot 343 \\
0 \cdot 252 \\
0 \cdot 390 \\
0 \cdot 450 \\
0 \cdot 355 \\
0 \cdot 391 \\
0 \cdot 388 \\
\overline{0} \\
0 \cdot 309 \\
0 \cdot 308 \\
0 \cdot 354 \\
0 \cdot 306 \\
0 \cdot 299 \\
0 \cdot 323 \\
0 \cdot 348 \\
0 \cdot 380 \\
0 \cdot 352 \\
0.292 \\
0.335\end{array}$ & $\begin{array}{l}7 \cdot 88 \\
8 \cdot 88 \\
8 \cdot 11 \\
6 \cdot 81 \\
7 \cdot 15 \\
8 \cdot 38 \\
8 \cdot 52 \\
8 \cdot 06 \\
7 \cdot 47 \\
7 \cdot 35 \\
6 \cdot 80 \\
7 \cdot 93 \\
4 \cdot 82 \\
8 \cdot 37 \\
6 \cdot 45 \\
7 \cdot 61 \\
7 \cdot 99 \\
6.98 \\
6 \cdot 94\end{array}$ & $\begin{array}{l}5 \cdot 15 \\
8 \cdot 33 \\
7 \cdot 70 \\
6 \cdot 34 \\
5 \cdot 95 \\
8 \cdot 05 \\
8 \cdot 29 \\
7 \cdot 96 \\
6 \cdot 78 \\
6 \cdot 86 \\
5 \cdot 79 \\
6 \cdot 63 \\
4 \cdot 49 \\
7 \cdot 89 \\
5 \cdot 71 \\
7 \cdot 01 \\
7 \cdot 36 \\
6 \cdot 45 \\
6 \cdot 45\end{array}$ \\
\hline $\begin{array}{l}\text { Mean } \\
\text { SD }\end{array}$ & $\begin{array}{l}59 \cdot 1 \\
(9 \cdot 6)\end{array}$ & & & $\begin{array}{c}23 \cdot 91 \\
(5 \cdot 13)\end{array}$ & $\begin{array}{c}0.07 \\
(0.02)\end{array}$ & $\begin{array}{l}26.97 \\
(6.83)\end{array}$ & $\begin{array}{c}34 \cdot 2 \\
(11 \cdot 7)\end{array}$ & $\begin{array}{c}0.343 \\
(0.045)\end{array}$ & $\begin{array}{c}7.50 \\
(0.91)\end{array}$ & $\begin{array}{c}6 \cdot 80 \\
(1 \cdot 06)\end{array}$ \\
\hline
\end{tabular}

* Only two segments available for morphometric studies.

*Only two segments available for morphometric studies.

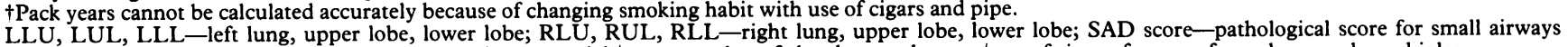
disease; DI-destructive index; L - mean linear intercept; AA $/ \mathrm{mm}$ - number of alveolar attachments/mm of circumference of membranous bronchioles.

lobes and there was a tendency to higher SAD scores in membranous and respiratory bronchioles in the upper lobes. There were no significant differences between upper and lower lobes with regard to $\mathrm{DI}$ and $\mathrm{Lm}$.

Table 4 shows the results of multiple regression analyses, parenchymal data being dependent variables and bronchiolar data, age, and cigarette pack years being independent variables. Total $\mathrm{AA} / \mathrm{mm}$ was correlated inversely with the SAD score for membranous and respiratory bronchioles and with wall thickness of membranous bronchioles, but not with age or pack years of smoking. The destructive index correlated with SAD score of respiratory bronchioles, wall thickness of membranous bronchioles and age, but not with SAD score of membranous bronchioles or with pack years of smoking. Mean linear intercept (Lm) correlated only with age.

\section{Discussion}

This study addressed the question of whether the presence and severity of small airways disease and parenchymal destruction are related, using several types of measurement. A close association between both disease processes would suggest a causal relation. Our data have shown significant inverse relations between the SAD score for membranous bronchioles and total and normal $\mathrm{AA} / \mathrm{mm}$, indicating a positive relation between small airways disease and destruction, or loss, of alveolar attachments. Wall thickness, which will reflect small airway inflammation, was also inversely correlated with $\mathrm{AA} / \mathrm{mm}$. In addition, the SAD score of respiratory bronchioles and wall thickness show significant positive correlations with the destructive index. Thus the lung specimens with small airways worst affected by pathological features showed the greatest parenchymal destruction.

If small airways disease and alveolar wall destruction are causally related, the two pathological conditions would be expected to share the same topographic distribution within the lung. In the present study this was investigated

Table 2 Spearman rank correlation coefficients with $p$ values for correlation between bronchiolar and parenchymal variables

\begin{tabular}{|c|c|c|c|c|c|c|c|c|}
\hline & \multicolumn{2}{|c|}{ Total $A A / \mathrm{mm}$} & \multicolumn{2}{|c|}{ Normal $A A / \mathrm{mm}$} & \multicolumn{2}{|l|}{$D I$} & \multicolumn{2}{|l|}{$L m$} \\
\hline & $r_{s}$ & $p$ & $r_{s}$ & $p$ & $r_{s}$ & $p$ & $r_{S}$ & $p$ \\
\hline $\begin{array}{l}\text { Membranous bronchioles } \\
\text { SAD score } \\
\text { Goblet cell metaplasia } \\
\text { Fibrosis } \\
\text { Wall thickness }\end{array}$ & $\begin{array}{l}-0.48 \\
-0.34 \\
-0.21 \\
-0.37\end{array}$ & $\begin{array}{l}0.01 \\
0.08 \\
0 \cdot 28 \\
0.06\end{array}$ & $\begin{array}{l}-0.51 \\
-0.36 \\
-0.29 \\
-0.45\end{array}$ & $\begin{array}{l}0.01 \\
0.06 \\
0.14 \\
0.02\end{array}$ & $\begin{array}{l}0.33 \\
0.48 \\
0.36 \\
0.50\end{array}$ & $\begin{array}{l}0.09 \\
0.01 \\
0.07 \\
0.01\end{array}$ & $\begin{array}{l}0.06 \\
0.08 \\
0 \cdot 19 \\
0 \cdot 23\end{array}$ & $\begin{array}{l}0 \cdot 78 \\
0 \cdot 08 \\
0 \cdot 34 \\
0 \cdot 25\end{array}$ \\
\hline $\begin{array}{l}\text { Respiratory bronchioles } \\
\text { SAD score } \\
\text { Goblet cell metaplasia } \\
\text { Fibrosis }\end{array}$ & $\begin{array}{l}-0.35 \\
-0.12 \\
-0.31\end{array}$ & $\begin{array}{l}0.07 \\
0.55 \\
0.12\end{array}$ & $\begin{array}{l}-0.32 \\
-0.16 \\
-0.28\end{array}$ & $\begin{array}{l}0 \cdot 10 \\
0 \cdot 42 \\
0 \cdot 16\end{array}$ & $\begin{array}{l}0.53 \\
0.49 \\
0.69\end{array}$ & $\begin{array}{ll} & 0.004 \\
0.01 \\
<0.001\end{array}$ & $\begin{array}{l}0.18 \\
0.27 \\
0.26\end{array}$ & $\begin{array}{l}0 \cdot 39 \\
0 \cdot 18 \\
0 \cdot 19\end{array}$ \\
\hline
\end{tabular}

For abbreviations see table 1. 


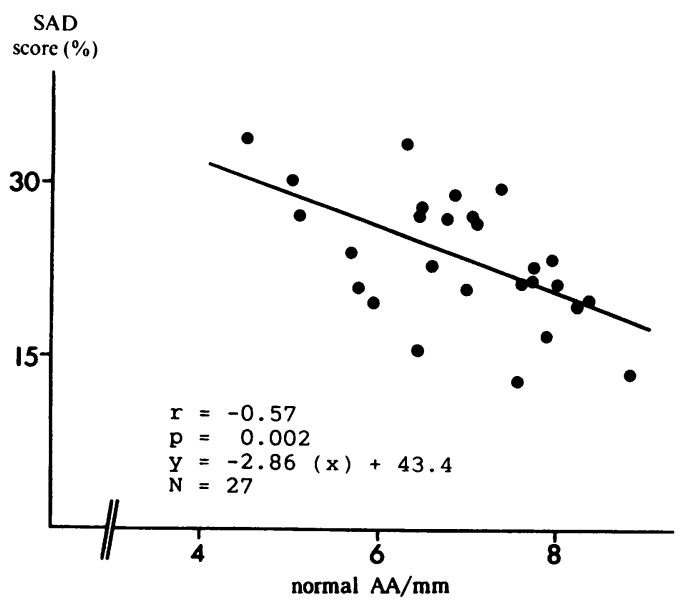

Figure 1 Number of normal alveolar attachments on membranous bronchioles/mm of circumference (normal $A A(\mathrm{~mm})$ plotted against the degree of small airways disease (SAD score) of membranous bronchioles. The Pearson correlation coefficient and the regression line are shown.

by comparing the data of the upper and lower lobes. There were significantly fewer alveolar attachments as well as a tendency to a greater degree of small airways disease in the upper lobe than in the lower lobe. This suggests that the same regions of the lung are vulnerable to small airway inflammation and disruption of peribronchiolar alveolar walls. To some extent this supports a causal association.

Age and cigarette smoking may affect these relationships, as both are linked with small airway and parenchymal disease. ${ }^{36}$ When smoking pack years and age were included as independent variables in a multiple regression analysis the SAD score of membranous and respiratory bronchioles and wall thickness were still correlated inversely with total $\mathrm{AA} / \mathrm{mm}$ (table 4). Thus the association between small airway inflammation and peribronchiolar destruction of parenchyma is most probably not just an epiphenomenon as the two main factors in this respect, age and smoking, did not confound the association. In our view this provides even stronger support for a causal association between small airways disease and centrilobular emphysema.

As smoking is an important aetiological agent in the pathogenesis of small airways disease and emphysema, it is remarkable that lung tissue from non-smokers had SAD scores and destructive indices of up to $30 \%$. Two points, however, should be made. Firstly, the pathological features of inflammation in air-

Table 3 Data for the upper and lower lobes: mean (SD) values with $p$ values for the two sample $t$ test

\begin{tabular}{|c|c|c|c|}
\hline & $\begin{array}{l}\text { Upper lobes } \\
(n=12)\end{array}$ & $\begin{array}{l}\text { Lower lobes } \\
(n=14)\end{array}$ & $p$ \\
\hline $\begin{array}{l}\text { Membranous bronchioles } \\
\text { SAD score }(\%) \\
\text { Wall thickness (mm) }\end{array}$ & $\begin{array}{l}25 \cdot 2(5 \cdot 7) \\
0.079(0.002)\end{array}$ & $\begin{array}{l}22 \cdot 1(5 \cdot 5) \\
0.065(0.010)\end{array}$ & $\begin{array}{l}0 \cdot 18 \\
0.06\end{array}$ \\
\hline $\begin{array}{l}\text { Respiratory bronchioles } \\
\text { SAD score (\%) }\end{array}$ & $26 \cdot 8(7 \cdot 0)$ & $21 \cdot 2(8 \cdot 1)$ & 0.07 \\
\hline $\begin{array}{l}\text { Parenchyma } \\
\text { DI }(\%) \\
\text { Lm (mm) } \\
\text { Total AA } / \mathrm{min} \\
\text { Normal AA } / \mathrm{min}\end{array}$ & $\begin{array}{l}29.7(0.051) \\
0.347(0.051) \\
7.25(0.95) \\
6.41(1.12)\end{array}$ & $\begin{array}{l}28.6(16.5) \\
0.323(0.059) \\
8 \cdot 11(0.74) \\
7.57(0.86)\end{array}$ & $\begin{array}{l}0.85 \\
0.32 \\
0.02 \\
0.008\end{array}$ \\
\hline
\end{tabular}

For abbreviations see table 1 .

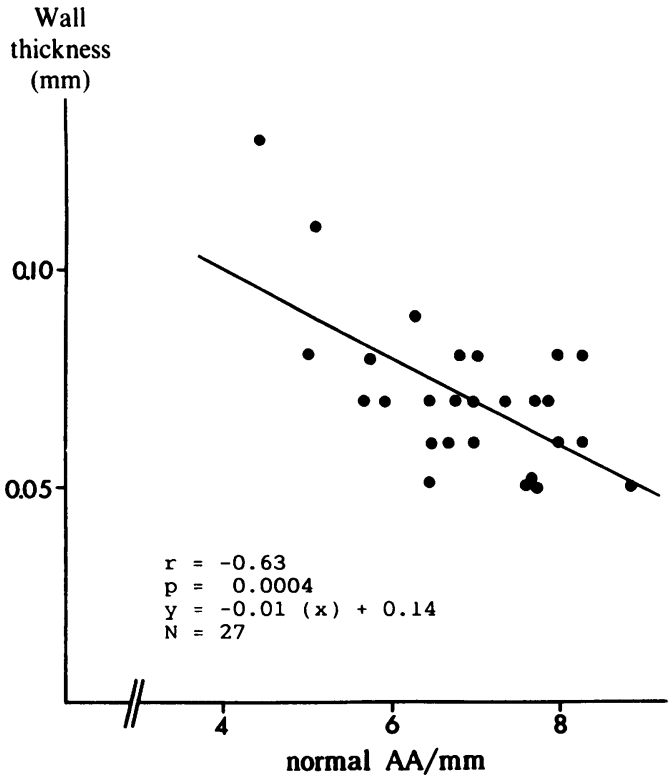

Figure 2 Number of normal alveolar attachments on membranous bronchioles/mm of circumference (normal $A A / \mathrm{mm}$ ) plotted against wall thickness of membranous bronchioles. The Pearson correlation coefficient and the regression line are shown.

ways and airspaces, as assessed by our morphometric techniques, are not specific for sequelae of cigarette smoking and may be induced by any noxious airborne irritation, such as industrial and traffic pollutants, allergens, respiratory infections, and-last but probably not least-passive smoking. Secondly, the morphometric techniques we used are not specific or diagnostic: they are a tool to quantify a pathological process in a way that is as unbiased and objective as possible for comparative and statistical purposes. Certainly these techniques have their limitations, and will measure abnormality in lung tissue that appears healthy to the experienced pathologist.

So far, three studies have compared the severity of small airways disease in the upper and lower lobes, obtaining three different results. ${ }^{31314}$ Perhaps there is indeed a topographical association between small airways disease and emphysema but in lungs with severe emphysema this association is disturbed: the most diseased bronchioles in the most emphysematous areas may have become fibrotic without other pathological features and may therefore have a low pathological score. Alternatively, these bronchioles may have disappeared in the emphysematous lesion. The resected lung specimens in our study came from individuals who were able to undergo thoracic surgery, and they are likely therefore to have had relatively mild disease. Loss of alveolar attachments may represent an early stage of emphysema, and accordingly we may have been able to find more destruction of these structures as well as a tendency to more severe small airways disease in the upper lobe, while upper and lower lobes were still similar in regard to the destructive index and linear intercept. Differences in the range of disease severity between the relatively small groups of patients in the different studies may at least partly explain the differences in the results. 
Table 4 Parameter estimates $(B)$ and $p$ values for multiple regression analyses ${ }^{\star}$

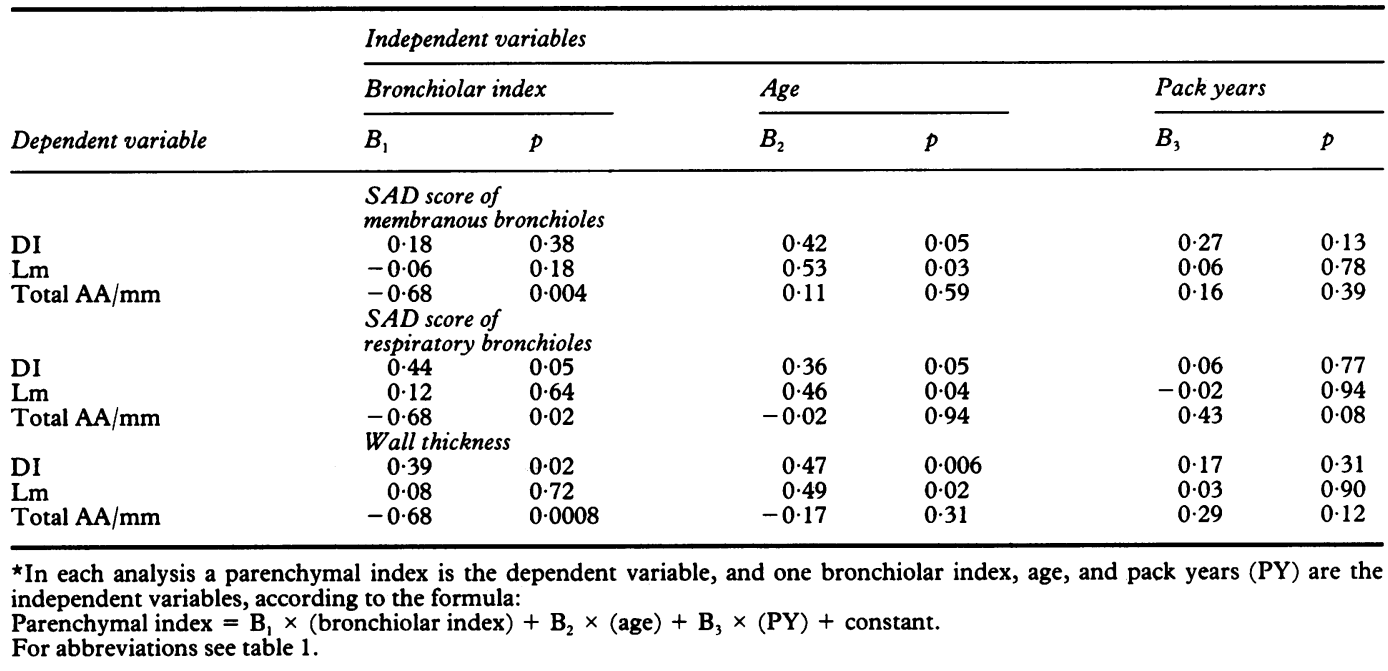

Two previous studies analysed the relation between the number of alveolar attachments and the degree of small airways disease. Saetta et $a l^{10}$ reported significant correlations between small airways disease of membranous bronchioles and three indices of loss of alveolar attachments. This is confirmed by our results. Petty $e t a^{11}$ found a significant inverse correlation between the mean number of attachments and the small airway fibrosis score only. They determined the mean number of attachments per cross sectioned bronchiole, through which bias may be introduced by bronchiolar dimension, larger bronchioles having a greater number of alveolar attachments. This may explain why the association between small airways disease and number of alveolar attachments in their study was not strong.

We have shown that features of small airways disease in membranous and respiratory bronchioles are related to loss of alveolar attachments; the association with destructive index was weaker and with linear intercept there was no association. These findings are in line with those of a study of Cosio and coworkers ${ }^{22}$ in smokers' lungs using scanning electron microscopy. These investigators found the greatest destructive changes of alveoli to be present in areas close to terminal airways. Perhaps loss of alveolar attachments may be regarded as reflecting the greater tendency to peribronchiolar wall disruption in centrilobular emphysema, and the destructive index and linear intercept as measuring the more diffuse disease pattern of panlobular emphysema or severe centrilobular emphysema. This is consistent with our observation that total and normal $\mathrm{AA} / \mathrm{mm}$ values were reduced to a greater extent in the upper lobe, corresponding to the topographic distribution of centrilobular emphysema, ${ }^{23}$ whereas we found no differences between upper and lower lobes in terms of destructive index and linear intercept.

Features of small airways disease have been shown to start earlier in life than emphysema. ${ }^{18}$ The first centrilobular emphysematous lesions have been reported to develop around areas of intense bronchiolar inflammation with peribronchiolar macro- phage accumulation. ${ }^{21824}$ All these observations support the view that small airways disease is directly and causally concerned in the development of centrilobular emphysema. According to this view, bronchiolar inflammation leads to destruction of the surrounding alveoli. Several mechanisms may be implicated. As proposed earlier by Saetta et al, ${ }^{10}$ byproducts of the inflammatory interactions in bronchioles possibly weaken surrounding alveolar walls and make them vulnerable to destruction. Rupture would then take place at the site where mechanical stress is probably the strongest, at the junction of the alveolar wall with the bronchiolar wall. ${ }^{25}$ Alternatively or additionally, the elastase-antielastase balance is disturbed by elastase released by inflammatory cells in the bronchiolar wall or by the macrophages, accumulating in adjacent alveoli, and the elastase then attacks elastic fibres in peribronchiolar alveoli directly. Elastase has been found on elastic fibres of the lung parenchyma, especially in emphysema ${ }^{26}$ though a more recent study has not been able to confirm this localisation of elastase. ${ }^{27}$ Of interest are some recent studies in which we found that the elastase inhibitor antileucoprotease was localised in association with elastic fibres in the walls of airways and alveoli. ${ }^{2829}$ Features of small airways disease and loss of alveolar attachments were associated with an increased amount of antileucoprotease in distal airways. ${ }^{30}$ Perhaps antileucoprotease is produced in increased amounts in response to both small airway inflammation and peribronchiolar parenchymal destruction, and these two conditions are causally related features of the same process.

In conclusion, in 27 surgically removed lungs and lobes we have shown a relation between loss of alveolar attachments and inflammatory changes in membranous and respiratory bronchioles that is not dependent on age or smoking habit. In our view these findings suggest that small airways disease is directly concerned in the causation of centrilobular emphysema.

This study was supported by grant 83.09 from 
the Netherlands Asthma Foundation. We wish to thank Mrs $\mathrm{G}$ van Leeuwen-Herberts and $\mathrm{Mr}$ $\mathrm{J}$ Brevée for histotechnical support, and Mrs E A van der Kwast for secretarial assistance. We are indebted to Dr J C Hogg (Vancouver) for his interest in our study, and to Dr M G Cosio (Montreal) for his discussion of and comments on our results.

1. Hogg JC, Macklem PT, Thurlbeck WM. Site and nature of airway obstruction in chronic obstructive lung disease. N Engl J Med 1968;278:1355-60.

2 Niewoehner DE, Kleinerman J, Rice DB. Pathologic changes in the peripheral airways of young cigarette smokers. $N$ Engl J Med 1974:291:755-8.

3 Cosio MG, Hale KE, Niewoehner DE. Morphologic and morphometric effects of prolonged cigarette smoking on morphometric effects of prolonged cigarette smoking on

4 Wright JL, Lawson LM, Paré PD, Wiggs BJ, Kennedy S, Hogg JC. Morphology of peripheral airways in curren smokers and ex-smokers. Am Rev Respir Dis 1983;127:474-7.

5 Snider GL, Kleinerman J, Thurlbeck WM, Bengali ZM The definition of emphysema. Report of a National Heart, Lung and Blood Institute Division of Lung Diseases Workshop. Am Rev Respir Dis 1985;132:182-5.

6 Sobonya RE, Burrows B. The epidemiology of emphysema. Clin Chest Med 1983;4:351-8.

7 Leopold JG, Gough J. The centrilobular form of hyperrophic emphysema and its relation to chronic bronchitis. Thorax 1957:12:219-35.

8 Anderson AE Jr, Foraker AG. Relative dimensions of bronchioles and parenchymal spaces in lungs from norma subjects and emphysematous patients. $\mathrm{Am} \mathrm{J} \mathrm{Med}$ 1962;32:218-28.

9 Janoff A. Elastases and emphysema. Current assessment of the protease-antiprotease hypothesis. Am Rev Respir $1985 ; 132: 417-33$.

10 Saetta M, Ghezzo H, Kim WD, King M, Angus GE, Wang $\mathrm{V}$, Cosio MG. Loss of alveolar attachments in smokers. A m, Cosio MG. Loss of alveolar attachments in smokers. A Rev Respir Dis 1985;132:894-900.

11 Petty TL, Silvers GW, Stanford RE. Radial traction and small airways disease in excised human lungs. Am Rev Respir Dis 1986;133:132-5.

12 Linhartova A, Anderson AE, Foraker AG. Radial traction and bronchiolar obstruction in pulmonary emphysema. Arch Pathol 1971;92:384-91.

3 Brend N. Lobar distribution of bronchiolar inflammation in emphysema. Am Rev Respir Dis 1981;124:218-20.

14 Wright JL, Wiggs BJ, Hogg JC. Airway disease in upper and lower lobes in lungs of patients with and without emphysema. Thorax 1984;39:282-5.

15 Petty TL, Silvers W, Stanford RE. Mild emphysema is associated with reduced elastic recoil and increased lung size but not with air-flow limitation. Am Rev Respir Dis 1987;136:867-71.

16 Hogg JC, Wright JL, Paré PD. Airways disease: evolution, pathology, and recognition. Med J Austr 1985;142:605-7.

17 Quanjer Ph H. Standardized lung function testing. Bul Eur Physiopathol respir 1983;19(suppl 5):1-95.

18 Cosio MG, Chezzo H, Hogg JC, et al. The relations between structural changes in small airways and pulmonaryfunction tests. N Engl J Med 1978;298:1277-81.

19 Saetta M, Shiner RJ, Angus GE, et al. Destructive index: a measurement of lung parenchymal destruction in smokers. Am Rev Respir Dis 1985;131:764-9.

20 Dunnill MS. Quantitative methods in the study of pulmonary pathology. Thorax 1962;17:320-8.

21 Thurlbeck WM. Measurement of pulmonary emphysema. Am Rev Respir Dis 1967;95:752-64.

22 Cosio MG, Shiner RJ, Saetta M, et al. Alveolar fenestrae in smokers. Relationship with light microscopic and funcsmokers. Relationship with light microscopic and func-

23 Thurlbeck WM. The incidence of pulmonary emphysema. Am Rev Respir Dis 1963;107:239-45.

24 McLaughlin RF, Tueller EF. Anatomy and histologic changes of early emphysema. Chest 1971;59:592-9.

25 Ranga V, Kleinerman J. Interalveolar pores in mouse lungs. Am Rev Respir Dis 1980;122:477-81.

26 Damiano VV, Tsang A, Kucich U, et al. Immunolocalization of elastase in human emphysema lungs. J Clin Invest 1986;78:482-93.

27 Fox B, Bull TB, Guz A, Harris E, Tetley TD. Is neutrophil elastase associated with elastic tissue in emphysema? Clin Pathol 1988;41:435-40.

28 Willems LNA, Otto-Verberne CJM, Kramps JA, HaveOpbroek ten AAW, Dijkman JH. Localization of antileukoprotease in the connective tissue of the lung. Histochemistry 1986;86:165-8.

29 Kramps JA, te Boekhorst AMT, Fransen JAM, Ginsel LA Dijkman JH. Antileukoprotease is associated with elastin fibers in the extracellular matrix of the human lung. $A m$ Rev Respir Dis 1989;140:471-6.

30 Willems LNA, Kramps JA, Stijnen Th, Sterk PJ, Weening JJ, Dijkman JH. Antileukoprotease containing bronchiolar cells: Relationship with morphologic disease of small airways and parenchyma. Am Rev Respir Dis 1989;139:1244-50. 